\title{
Three new libelluline dragonflies from southern Venezuela, with new records of other species (Odonata: Libellulidae)
}

\author{
Jürg De Marmels \\ Museo del Instituto de Zoología Agrícola "Francisco Fernández Yépez" (MIZA), \\ Facultad de Agronomía, Universidad Central de Venezuela, \\ Apartado 4579, Maracay 2101-A, Venezuela. \\ $<$ demarmjc@gmail.com>
}

Key words: Odonata, dragonflies, Libellulidae, Anisoptera, Venezuela, new species, new records.

\begin{abstract}
Elasmothemis rufa sp. nov. (holotype: Venezuela, Amazonas, Río Cataniapo), Macrothemis taurepan sp. nov. (holotype: Venezuela, Bolívar, El Paují), and Oligoclada garrisoni sp. nov. (holotype: Venezuela: Amazonas, San Fernando de Atabapo) are described and illustrated. All holotypes are deposited at MIZA. Macrothemis heteronycha and Micrathyria paruensis are recorded from Venezuela for the first time, and Micrathyria dunklei for the second. Some of their features are illustrated. Distribution maps of all these species are also presented.
\end{abstract}

\section{INTRODUCTION}

Some unidentified libelluline dragonflies from southern Venezuela, which for many years remained unexamined in a box, together with a few more recently collected and also undetermined specimens, were finally examined and identified. Most of them showed to be either new to science or first records for Venezuela.

\section{Methods}

Wing vein nomenclature follows Riek \& Kukalovà-Peck (1984). Right wing features are given in parentheses, if differing from left wing; same for other paired structures, viz. cerci. Cux = cross-veins in the cubital space; if only one vein present, this being $\mathrm{CuP}$. Length of pterostigma refers to costal length of forewing pterostigma. Length of hindwing includes only membranous part, excluding root. Total length includes cerci, length of abdomen does not. All dimensions are given in millimeters. Drawings were made using a camera lucida coupled to a Wild M-8 stereoscope. All specimens are deposited in the Museo del Instituto de Zoología Agrícola "Francisco Fernández Yépez" (MIZA), Facultad de Agronomía, Universidad Central de Venezuela, Maracay, Venezuela. 


\section{Elasmothemis rufa sp. nov.}

(Figs 1, 2, 3)

\section{Etymology}

'Rufa' (Latin) means red, referring to the bright red male abdomen.

\section{Specimens examined}

Holotype ơ: Venezuela, Amazonas State, Río Cataniapo, $10 \mathrm{~km} S$ Puerto Ayacucho, 09 iii 1984, O.S. Flint leg. (MIZA, no. 17440). — Paratypes: 3 o": same data as holotype (MIZA , nos 17441-17443; 1 ơ: Upper Río Ventuari, Cácuri, 21 xi 1959, J.M. Cruxent leg. (MIZA no. 17436). - Female and larva unknown.

\section{Description of male holotype}

Head: Labium yellow brown, labrum and face (except for yellow anteclypeus), frons above, vertex and occipital triangle bright orange; vertex bi-tuberculate; rear of head orange brown with yellow spot behind compound eye at about half its vertical extension; antenna brown.

Thorax: pale brown ochreous, but pronotal hindlobe and mesepisternum orange; traces of narrow yellow cross-band in front of metathoracic spiracle, and some yellow also along distal dorsal angle of metepimeron. - Legs dark red brown, proximal portion of femora paler. - Wings very slightly smokey with yellow tinge at extreme base, especially in cubital space; extreme wing tips (marginal cell row) brown, membranula grey brown. Main veins basally red, becoming darker towards

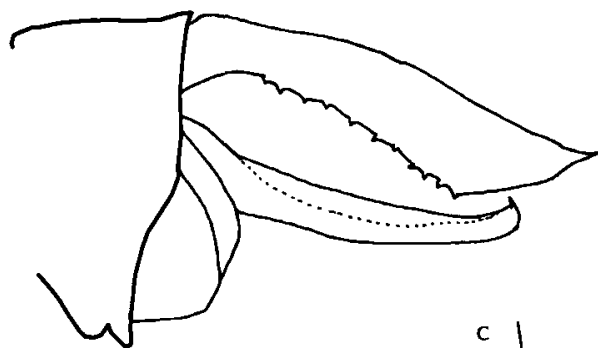

d

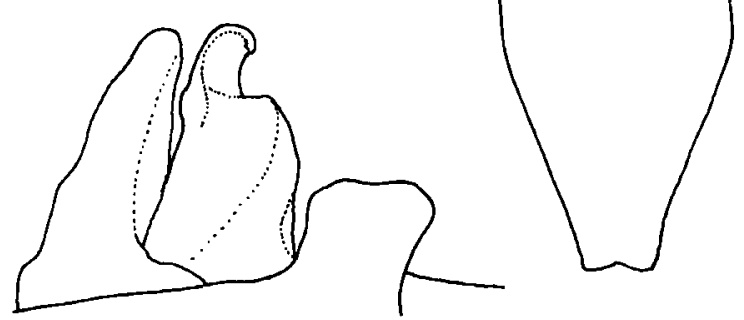

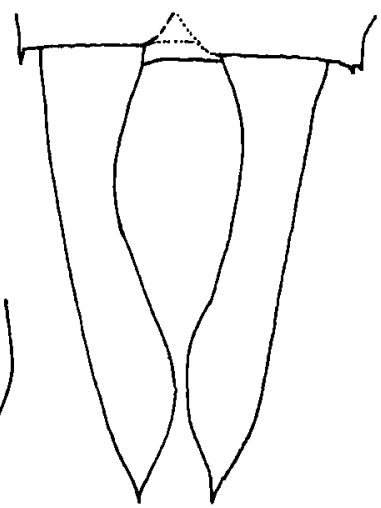

Figure 1: Elasmothemis rufa sp. nov., male holotype - (a) caudal appendages, left lateral view; (b) same, dorsal view; (c) epiproct, ventral view; (d) secondary genitalia, hairs omitted, right lateral view. 
nodus and beyond; pterostigma brown. $12.5 \mathrm{Ax}$ in $\mathrm{Fw}, 9$ in $\mathrm{Hw} ; 10 \mathrm{Px}$ in all wings, except left Hw (9); Fw with 2 (1) Cux, Hw with 3 (2); Rspl in Fw with 2 doublecells, Hw with $1(0)$.

Abdomen: Uniformly bright cinnabar red, except for S1 and S2, and proximal portion of S3, which have some yellow laterally; median transverse carina and lateral carina of S3 red, lateral carina of remaining segments narrowly black. Cercus in lateral view little slanting, its ventral surface bearing $11(10)$ irregular teeth (Fig. 1a); cerci in dorsal view convergent rearwards, apical spines of cerci parallel (Fig. 1b); epiproct (Fig. 1c) reaching to $2 / 5$ of the distance between last tooth and tip of apical spine of cercus. Hamulus slightly surpassing tip of anterior lamina, genital lobe broader than half of hamulus at base (Fig. 1d).

Dimensions: Total length 43.0; abdomen 27.0; cercus 2.0; Hw 32.0; pterostigma 3.5.

\section{Paratype males}

All specimens closely resemble the holotype. One male has almost hyaline wings (except for obligate yellowish wing bases), one male lacks any brown at wing tips. Wing venation differs only marginally from that of holotype: 11.5-13.5 (mostly 12.5) Ax in Fw, 8-9.5 (mostly 9) in Hw; 9-10 Px in Fw, 9-11 in Hw; Rspl in Fw with 2-4 double-cells, in Hw 1 or none. Hamulus as high as anterior lamina in all males. Penis varies in size and shape; penes of two paratypes are illustrated (Figs $2 a-c$ ).

a

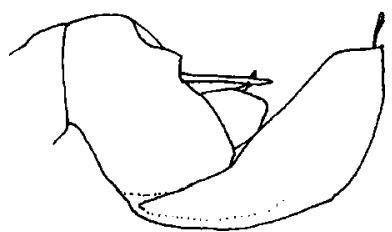

$\mathrm{b}$

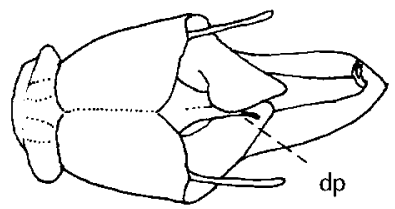

C

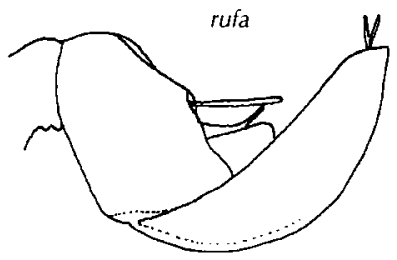

d

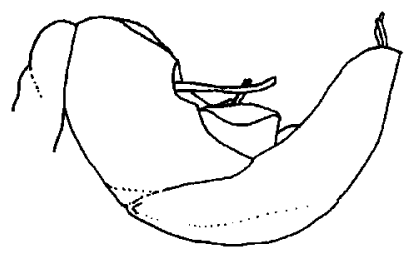

e

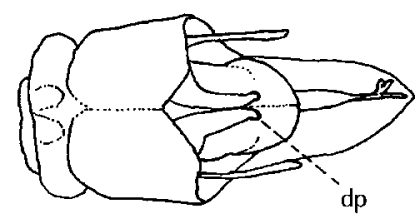

f

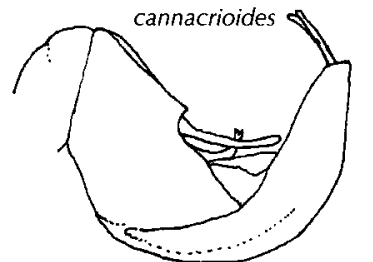

Figure 2: Penes of Elasmothemis rufa sp. nov. (a-c) and E. cannacrioides ( $d-f)$ in comparison (a) paratype no. 17441, right lateral view; (b) same, ventral view; (c) paratype no. 17442, right lateral view; (d) specimen from south of the Orinoco, Culebra, Amazonas State, right lateral view; (e) same, ventral view; $(f)$ specimen from north of the Orinoco, Canoabo, Carabobo State, right lateral view; all Figures to scale; dp: dorsomedian process. 
Dimensions: Total length 41-45.5; abdomen 26-28.5; cercus 2.0; Hw 31.5-32.5; pterostigma 3.6-4.0.

\section{Diagnostic remarks}

The new species can be separated from E. cannacrioides Calvert, 1906 (Figs 2d-f) by its uniformly bright cinnabar red abdomen. The lateral carina on distal half of $S 3$ is always red in the new species, but black in E. cannacrioides. This latter species also lacks any yellow at wing bases. Structural differences in either wing venation, genital armature or caudal appendages were not observed, although the pair of dorsomedian processes (dp) of the distal penis segment (Figs $2 \mathrm{~b}, \mathrm{e}$ ) tends to be narrower in the new species. In Venezuela populations of E. cannacrioides from north of the Orinoco river differ somewhat from populations south of it: Southern males usually have 12.5 or more $\mathrm{Ax}$ in $\mathrm{Fw}$ and $10 \mathrm{Ax}$ in $\mathrm{Hw}$, whereas males from north of the Orinoco more often have only 11.5 Ax in Fw and 9 or less Ax in Hw. Furthermore, southern males have strongly contrasting abdominal pattern of ochreous and ferruginous with black, while northern males show a more uniform, vermilion abdomen (De Marmels 1989).

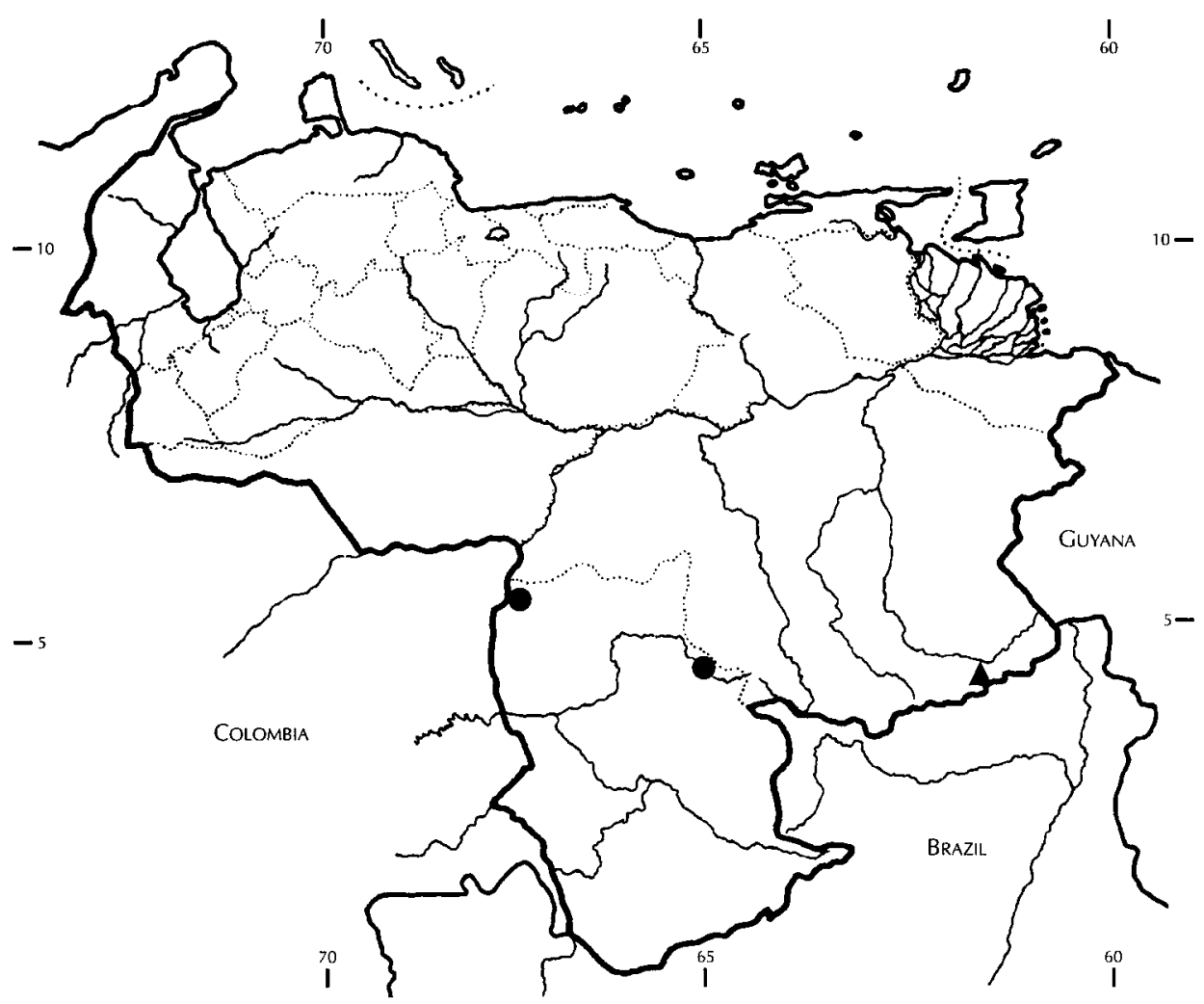

Figure 3: Records of (-) Elasmothemis rufa sp. nov. and ( $\mathbf{\Delta})$ both Macrothemis heteronycha and $M$. taurepan sp. nov. in Venezuela. 


\section{Macrothemis heteronycha (Calvert, 1909)}

(Figs 3, 4)

Specimen examined

1 ơ: Venezuela, Bolívar State, Sierra Pacaraima, El Paují, 882 m (4²8’06"N, $61^{\circ} 35^{\prime} 39^{\prime}$ W), 17 iv 2006, J. Perozo leg. (MIZA no. 17385).

\section{Remarks}

This species was heretofore known only from southern Brazil, Paraguay and Argentina (Rodrigues Capitulo \& Muzón 1989) and is here for the first time recorded from Venezuela and from north of the Amazon. It keys out with $M$. absimilis Costa, 1991 in the most recent key to males of Macrotbemis proposed by May (1998). May's key does not, however, include M. heteronycha, following Bridges (1994),
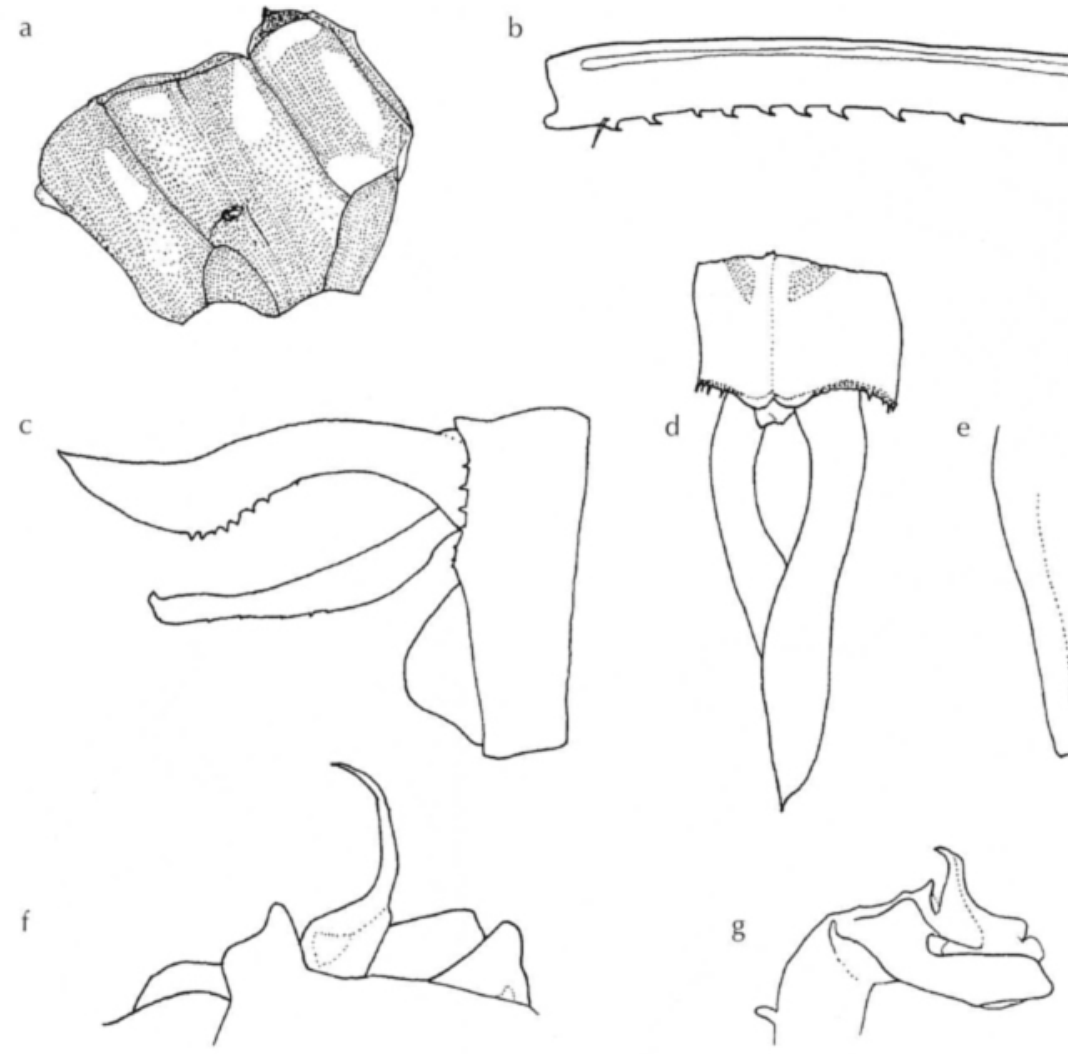

Figure 4: Macrothemis heteronycha, male - (a) pterothorax, right lateral view; (b) right hind femur, right lateral view; (c) caudal appendages, right lateral view; (d) same, dorsal view; (e) epiproct, ventral view; ( $f$ ) secondary genitalia, hairs omitted, left lateral view; (g) penis, right lateral view; $(c-f)$ to scale. 
who listed that species under Gynothemis. Recently, Garrison \& von Ellenrieder (2006) placed G. heteronycha in Macrothemis. In the same paper, these authors present figures of the penis and hind femur of a male from southern Brazil.

The Venezuelan male differs from this and other described specimens (Calvert 1909, sub Brechmorhoga; Ris 1913, sub Gynothemis) in having only nine spines in the outer row of both hind femora (Fig. 4b). The lateral lobe of penis is straight in the Venezuelan male (Fig. $4 \mathrm{~g}$ ), but curved dorsad apically in the male illustrated by Garrison \& von Ellenrieder (2006: fig. 35). Claws of second and third tarsi are asymmetrical, as described by these authors, i. e., the outer claw being shorter than inner claw, and with tooth longer than tip. There are 9.5 (8.5) $\mathrm{Ax}$ in $\mathrm{Fw}, 7 \mathrm{Ax}$ in $\mathrm{Hw}$; $5 \mathrm{Px}$ in $\mathrm{Fw}, 6 \mathrm{Px}$ in $\mathrm{Hw}$; arculus slightly distally of $2^{\text {nd }} \mathrm{Ax}$ in $\mathrm{Fw}$, more so in $\mathrm{Hw}$; all triangles free, subtriangle in Fw two-celled (free); discoidal field in Fw two-rowed, only slightly narrowing near anal border of wing, in $\mathrm{Hw}$ beginning with two cells, of which the distal one is the only entire cell between MA and MP; Rspl in Fw enclosing 5 (6) cells, in Hw 7 (6); Mspl absent; 1 (2) Cux in Hw; anal loop enclosing 10 cells; two rows of post-loop cells in Hw.

Dimensions: Total length 35.7; abdomen 25.0; cercus 1.7; Hw 25; pterostigma 2.0.

\section{Macrothemis taurepan sp. nov.}

(Figs 3, 5)

\section{Etymology}

The Taurepán is a local section of the Pemón Amerindian tribe. The name is here used as a noun in apposition.

\section{Specimen examined}

Holotype ơ: Venezuela, Bolívar State, Sierra Pacaraima, El Paují, 860 m, 25 iv 2004, J. Camacho leg. (MIZA no. 17437). - Female and larva unknown.

\section{Description of male holotype}

Head: Labium yellowish, lateral lobes narrowly orange along anterior and mesal margins, median lobe brown posteriorly; labrum orange, clypeus brown, vertical portion of frons orange laterally and narrowly along fronto-clypeal suture, remainder of frons, vertex and antenna shiny black; occipital triangle dark brown, rear of head yellow brown.

Thorax: Mesepisternum shiny black, pale antehumeral stripes rudimentary, commashaped and confined to lower fourth of sclerite, but transverse bar below antealar carina greenish white; median carina black with extreme dorsal edge of proximal two thirds of its length narrowly white; lateral parts of pterothorax brown black with greenish white marks as illustrated (Fig. 5a). - Legs pale brown, tarsi black; hind femur with 10 (11) sharply triangular spines (Fig. 5b); tip of claws of fore tarsus little longer than respective inferior tooth, mid and hind tarsi have longer inferior tooth at outer claw, and inferior tooth of same length as tip on inner claw. - Wings hyaline with a very weak yellowish tinge in discal area; venation black, pterostigma dark brown, membranula grey brown. 11.5 (10.5) Ax in Fw, 7 in Hw; 
$7 \mathrm{Px}$ in all wings, except in left $\mathrm{Fw}(6)$. Arculus at $2^{\text {nd }} \mathrm{Ax}$ in Fw, more distally in $\mathrm{Hw}$; all triangles free, subtriangle in Fw free (two-celled), Rspl enclosing 6 cells in all wings, except for right $\mathrm{Hw}$ (7); Mspl absent; anal loop enclosing 12 (11) cells; two rows of postloop cells in Hw. Discoidal field of Fw two-rowed, slightly narrowing near anal border of wing, in Hw beginning with two cells of which the distal cell and two following cells are entire between MA and MP; only $1 \mathrm{Cux}$ in $\mathrm{Hw}$ (= CuP).

Abdomen: Moderately expanded between S7 and S9, mostly black; pale brown (yellow in life?) are: lateroventral portion of S1 and S2, a dorsal and a lateral spot on S2, a laterobasal mark in basal half and an ill-defined dorsolateral longitudinal streak (this latter one broadly interrupted at median transverse carina) on S3; ventral portion of terga of S3-7 yellow brown; cercus black, epiproct brown (Figs 5c-e); secondary genitalia as illustrated (Figs $5 \mathrm{f}-\mathrm{h}$ ).

Dimensions: Total length 28.2; abdomen 18.0; cercus 1.2; Hw 22.0; pterostigma 1.4.

\section{Diagnostic remarks}

This species falls together with M. ludia Belle, 1987 and M. musiva Calvert, 1898 in May's (1998) key. These two species have, however, a cylindrical and much longer abdomen, different femoral armature, different shape of cercus and penis, and also

a

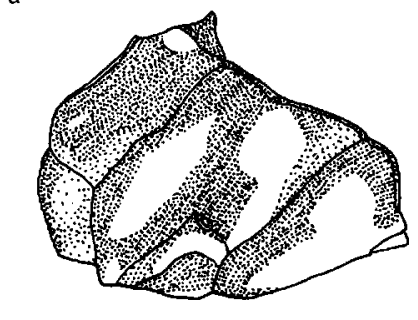

C
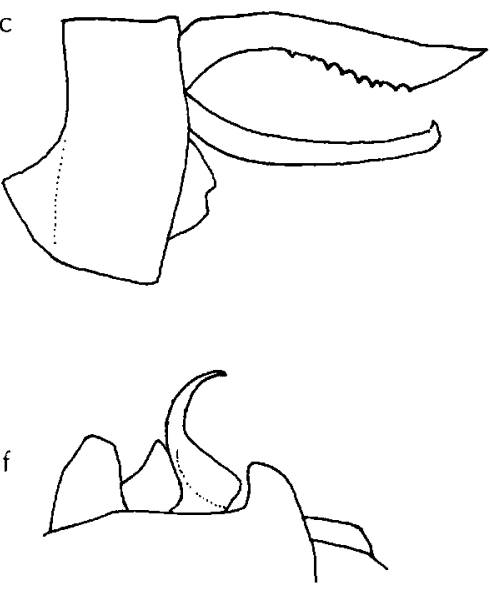

b
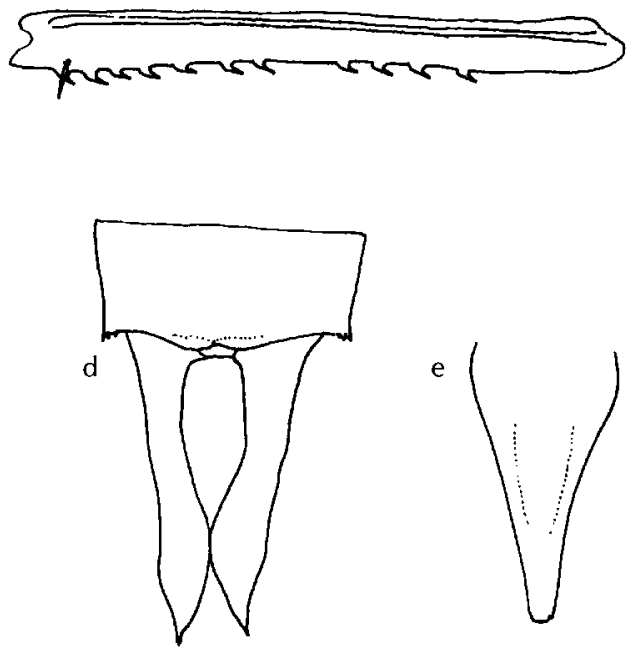

g

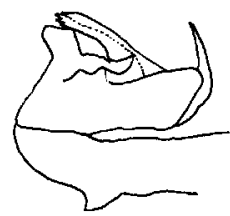

h

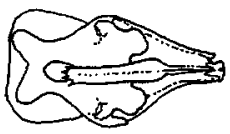

Figure 5: Macrothemis taurepan sp. nov., holotype male - (a) pterothorax, left lateral view; (b) right hind femur, right lateral view; (c) caudal appendages, left lateral view; (d) same, dorsal view; (e) epiproct, ventral view; (f) secondary genitalia, hairs omitted, right lateral view; (g) penis, right lateral view; (h) same, ventral view; (c-f) to scale. 
a different color pattern. Illustrations of the penis of Venezuelan M. musiva are presented in Figure 6. When compared with the figure in Garrison \& von Ellenrieder (2006: fig. 33) of a south Brazilian specimen, the sclerotized dorsomedian spine (s) near the base of the apical segment of the penis is much longer in this specimen than in the males from Venezuela. M. ludia, M. musiva and $M$. taurepan are sympatric in the Pacaraima Mts.

a

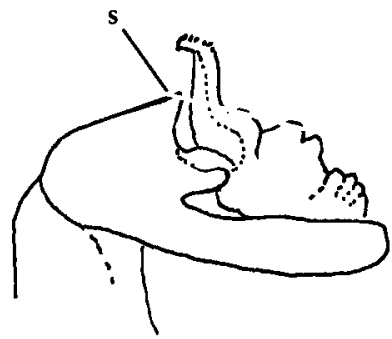

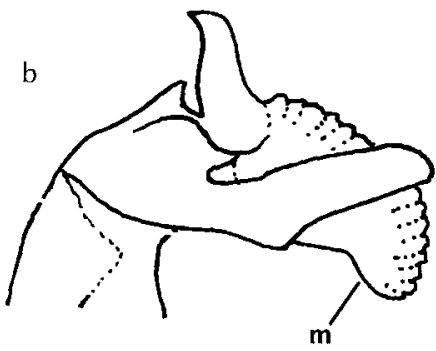

Figure 6: Macrothemis musiva, male - (a) penis showing dorsomedian spine (s), right lateral view of specimens from Santa Lucía, road between Santa Elena de Uairén and Icabarú, Bolívar State; (b) same with median lobe $(m)$ inflated, but from La Mariposa, Miranda State.

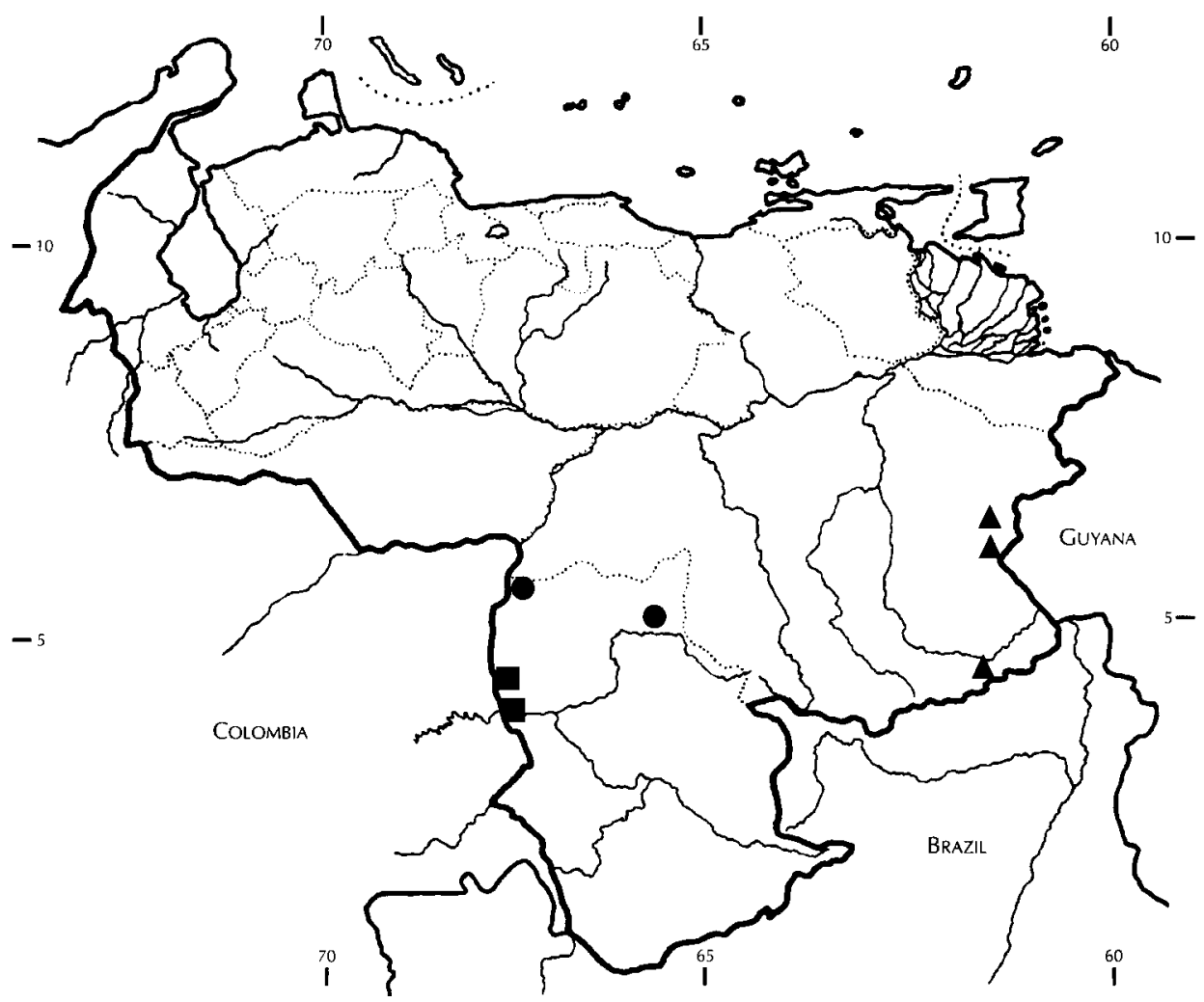

Figure 7: Records of Micrathyria dunklei; ( $\mathbf{\Delta})$ M. paruensis;

Oligoclada garrisoni sp. nov. in Venezuela. 


\section{Micrathyria dunklei Westfall, 1992}

(Figs 7, 8)

\section{Specimen examined}

1 ơ, Venezuela, Amazonas State, Puerto Ayacucho, 28 x 1983, J. Sánchez leg.

\section{Descriptive notes}

An immature male, which differs from the holotype in having a yellow spot also on metakatepisternum above coxa, and a yellow lateral streak in basal half of S2 and S3, as well as a very tiny yellow lateral line on $\mathbf{S 6}$. Tip of epiproct is only one sixth as broad as maximum width at base; there are no teeth on cercus, but two minute, black tubercles near ventral angle (Fig. 8b). Secondary genitalia as illustrated (Figs 8c-e). Dimensions: Total length 27.7; abdomen 17.5; cercus 1.2; Hw 20.0.

\section{Remarks}

The single specimen had been stored since 1983 in the 'unidentified species box' at MIZA. After the original description of M. dunklei by Westfall (1992) based on material from Brazil (Rondônia State), Paulson (2001) produced the first Venezuelan record, also from the Amazonas State, but more to the east than the present locality (Fig. 7).

a

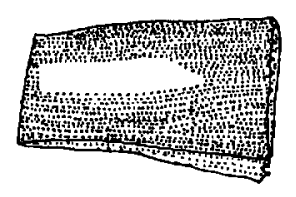

b
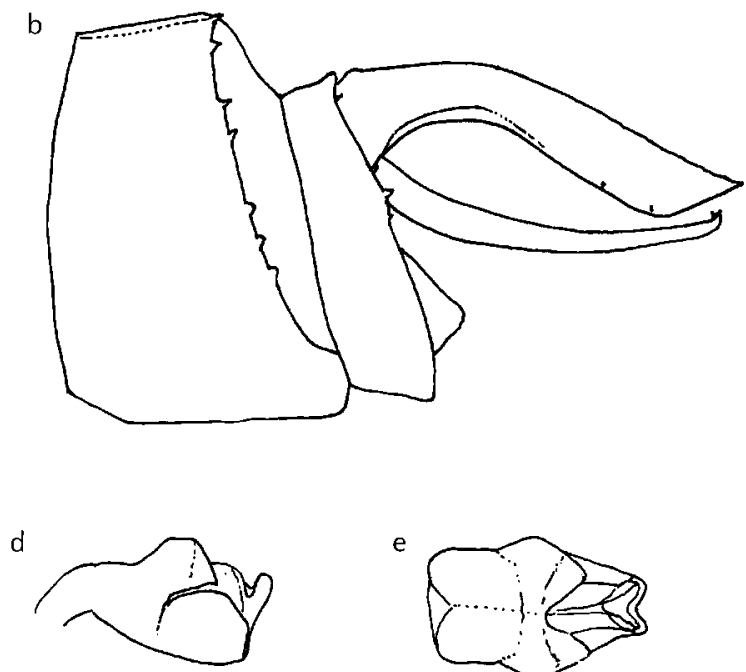

e

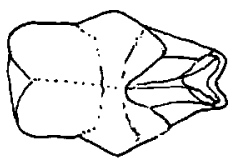

Figure 8: Micrathyria dunklei, male - (a) S7, left lateral view; (b) S9 and S10 with caudal appendages, left lateral view, note lack of ventral teeth on cercus; (c) left hamule, ventral view; (d) penis, right lateral view; (e) same, ventral view. 


\section{Micrathyria paruensis Geijskes, 1963}

(Figs 7,9 )

\section{Specimens examined}

1 o", Venezuela, Bolívar State, km 38 road El Dorado-Santa Elena de Uairén, 03 iv 1957, F. Fernández Yépez \& C. J. Rosales leg.; 1 o", same, but km 85, 20 vii 1971, Duque leg.; 1 đ", road Santa Elena de Uairén-Icabarú, near Río Surukum, 20-31 i 1985, J. De Marmels leg.

\section{Remarks}

All three males correspond well with the original description by Geijskes (1963) of the type series from Brazil, near the border with Surinam. Here I illustrate the penis of a specimen from Venezuela (Figs 9a, b). The present record is the first of M. paruensis from this country.

Figure 9: Micrathyria paruensis, male (a) penis, left lateral view; (b) same, ventral view.

\section{a}
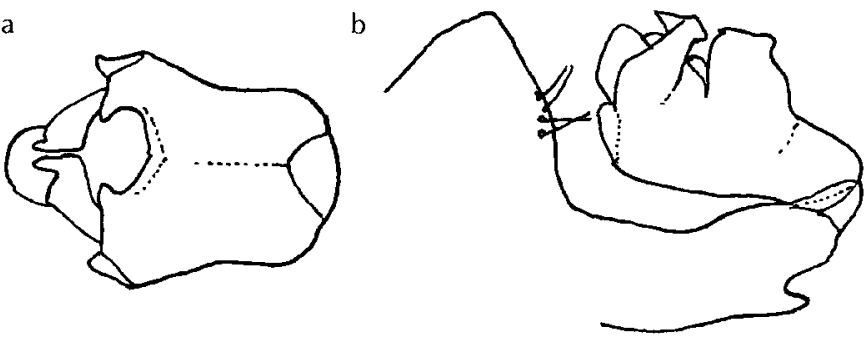

Oligoclada garrisoni sp. nov.

\section{Etymology}

I dedicate this species to Rosser W. Garrison not only for his outstanding contributions to odonatology of the Americas, but also in recognition of his unselfish readiness to collaborate whenever asked for.

\section{Specimens examined}

Holotype ơ: Venezuela, Amazonas State, San Fernando de Atabapo, 23 ii 1957, J. Rácenis leg. (MIZA no. 6464). - Paratypes: 1 o, same data as holotype (MIZA no. 6467); 1 ơ, same, but 25 ii 1957 (MIZA no. 6465), both J. Rácenis leg.; 2 ơ, Río Sipapo, 22 iii 1957, no collector (MIZA nos 6463, 6466).

\section{Description of male holotype}

Head: Labium yellow with very narrow, brown line across centre of median lobe and along mesal margin of lateral lobe below apical hook; face yellow up to halfheight of vertical part of frons, frons above and vertex metallic blue; occipital triangle black with yellow twin-spot posteriorly, on vertical part; rear of head black. 
Thorax: Almost black, with blue pruinosity at about those parts which are yellow in female (see below, Fig. 10f). Legs black; tooth of claws as a short, triangular projection directed ventrad, located at about two thirds of claw's length. Wings weakly smokey; antenodal portion of $\mathrm{Fw}$ little shorter than postnodal one; pterostigma amber yellow, venation black, membranula brown; no basal spot in either wing. There are $7 \mathrm{Ax}$ in $\mathrm{Fw}$ (all complete), 6 in $\mathrm{Hw} ; 7$ (8) Px in Fw, 8 in Hw; Rspl of all wings enclosing 4-5 cells; triangle and subtriangle in Fw free; discoidal field of $\mathrm{Fw}_{\mathrm{w}}$ with two cell-rows to about nodus, then three rows; three (two) undivided cells after triangle in $\mathrm{Hw}$ between MA and MP; costal edge of Fw triangle unbroken, Hw triangle free. Anal loop enclosing 10 (12) cells, including accessory cell at heel; only one cell-row between anal loop and hind border of wing. No cross-veins in cubital space besides CuP.

Abdomen: Black with some bluish pruinosity dorsally, brown black ventrally (not noticeably reddish on S7-9); accessory transverse carina of S4 weakly indicated. Cercus in lateral view (Fig. 10a) narrow, straight in basal half, then suddenly inflated ventrally and beset with a row of four short, somewhat externally located denticles, inflated portion of cercus ending apically in a short spine. Cerci in dorsal view subparallel, swollen apical halves little diverging towards tip (Fig. 10b); epiproct broad basally (Fig. 10c). Anterior lamina lower than hamulus; hamulus a sickle-shaped, widely open hook sitting on a short, rather narrow base; genital lobe little surpassing hamulus in length, higher anteriorly than posteriorly (Fig. 10d).

Dimensions: Total length 27.2; abdomen 17.0; cercus 1.2; Hw 19.5; pterostigma 1.7.

a

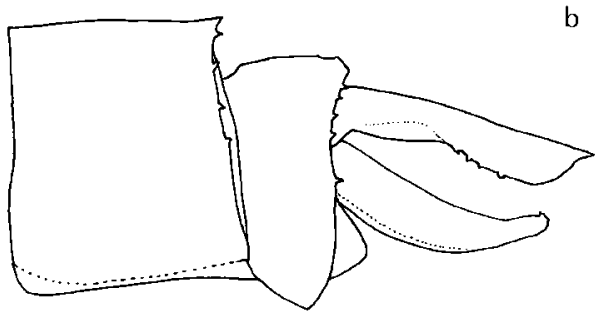

d

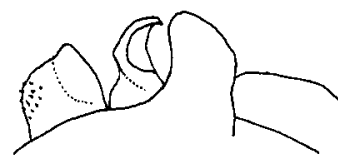

e

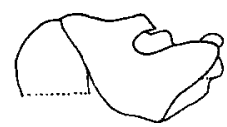

$b$
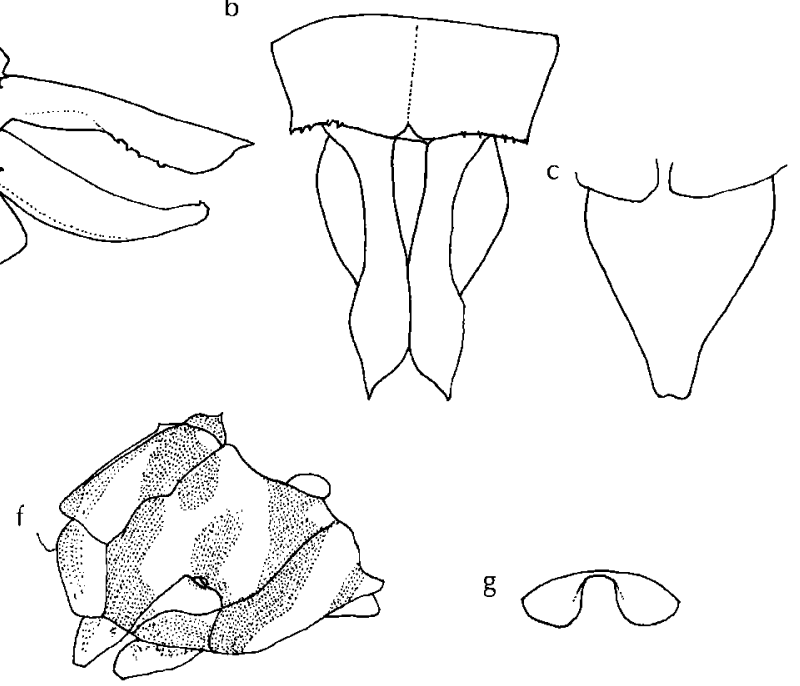

$\mathrm{g}$

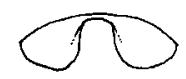

Figure 10: Oligoclada garrisoni sp. nov., holotype male (a-d) and paratypes (e-g) - (a) S9 and S10 with caudal appendages, left lateral view; (b) S10 with caudal appendages, dorsal view; (c) epiproct, ventral view; (d) genital armature, right lateral view - all Figures to scale; (e) penis, right lateral view; (f) pterothorax of female, left lateral view; $(g)$ vulvar lamina, ventral view. 
Paratype males

Similar to holotype. Occipital triangle lacking yellow spots posteriorly. 7-8 px in Fw, 6-8 px in Hw; Rspl enclosing 4-5 cells; anal loop with 11-12 cells, of which 1-2 are accessory cells at heel; accessory transverse carina on S4 well marked in one male from San Fernando, moderately or not developed in males from Sipapo; cercus with 4-5 teeth; one male from Sipapo has ventral side of S7-9 rufous. Penis (three males examined) with short apical segment, and with lateral lobes short, truncated distally and directed upwards; cornua absent (Fig. 10e).

Dimensions: Total length 27.6-29.0; abdomen 16.7-17.2; cercus 1.1-1.3; Hw 19.521.0; pterostigma 1.6-1.8.

\section{Paratype female}

Head: Frons and vertex pale brown, each with only basal stripe darker with some metallic blue reflections; occipital triangle yellow without any kind of processes. Other features as in male.

Thorax: Dark brown with yellow markings (Fig. 10f). Legs as in male. Wings hyaline with pale amber clouding in subcostal and cubital spaces; pterostigma pale yellow. $8 \mathrm{Ax}$ in Fw, 6 in Hw; 7 px in both wings; 12 cells in anal loop, including an accessory cell at heel in left $\mathrm{Hw}$. One cell-row between anal loop and hind margin of wing, basally to level of arculus two rows.

Abdomen: S1-3 pale brown dorsally, yellowish in basal half; S4-8 pale brown dorsally, dark brown to black laterally and distally; S9 and 10 dark brown dorsally, paler laterally. Cercus little longer than S10, dark brown and bearing an apical spine. Vulvar lamina as illustrated (Fig. 10g).

Dimensions: Total length 26.5; abdomen 17.0; Hw 21.0; pterostigma 2.0.

\section{Diagnostic remarks}

In Borror's (1931) key the new species falls together with O. stenoptera Borror, 1931 and O. rhea Ris, 1911. It differs from O. stenoptera in having a much shorter apical penis segment and differently shaped lateral lobes. Judging from Borror's figure 15 and illustrations kindly forwarded to me by Rosser Garrison of an Ecuadorian specimen in his collection, the genital lobe is broader and rather regularly rounded in O. stenoptera, but narrower and slightly tapering anteriorly in O. garrisoni. From O. rhea the new species differs in cercal morphology. In the MIZA collection there are specimens of O. monosticha Borror, 1931 and of O. sylvia (Kirby, 1889) from San Fernando de Atabapo, the latter species also from the Río Sipapo.

\section{ACKNOWLEDGEMENTS}

I thank Rosser W. Garrison, Sacramento, for sending me figures of a male O. stenoptera in his collection. To Quintín Arias I am indebted for scanning and editing the figures. Finally, I wish to thank Rosser Garrison, Natalia von Ellenrieder and KlaasDouwe Dijkstra for peer-reviewing the manuscript. 


\section{REFERENCES}

Borror, D.J., 1931. The genus Oligoclada (Odonata). Miscellaneous Publications Museum of Zoology University of Michigan 22: 5-42, pls I-VII.

Bridges, C.A., 1994. Catalogue of the family-group, genus-group and species-group names of the Odonata of the world (third edition). Bridges, Urbana.

Calvert, P.P., 1909. Contributions to a knowledge of the Odonata of the neotropical region, exclusive of Mexico and Central America. Annals of the Carnegie Museum 6: 73-280.

De Marmels, J., 1989. Odonata or dragonflies from Cerro de La Neblina and the adjacent lowland between the Río Baría, the Casiquiare and the Río Negro (Venezuela). I. Adults, and II. Additions to the adults. Boletín de la Academia de las Ciencias Físicas, Matemáticas y Naturales, Caracas 25: 11-78, 81-91.

Garrison, R.W. \& N. von Ellenrieder, 2006. Generic diagnoses within a closely related group of genera: Brechmorhoga, Gynothemis, Macrothemis and Scapanea (Odonata: Libellulidae). Canadian Entomologist 138: 269-284.

Geijskes, D.C., 1963. Three new species of Micrathyria with a note on M. romani Sjöstedt. Notes on Odonata of Suriname VIII. Studies on the fauna of Suriname and other Guyanas 5: 70-84.

May, M.L., 1998. Macrothemis fallax, a new species of dragonfly from Central America (Anisoptera: Libellulidae), with a key to male Macrothemis. International Journal of Odonatology 1: 137-153.

Paulson, D., 2001. A Venezuelan odonate vacation. Argia 13 (1): 7-9.

Riek, E.F. \& J. Kukalovà-Peck, 1984. A new interpretation of dragonfly wing venation based upon Early Upper Carboniferous fossils from Argentina (Insecta: Odonatoidea) and basic character states in pterygote wings. Canadian Journal of Zoology 62: 1150-1166.

Ris, F., 1913. Libellulinen monographisch bearbeitet, Vol. 3. Libellulinen 7. Collections Zoologiques du Baron Edm. de Selys Longchamps. Catalogue Systématique et Descriptif 15: 837-964, pl. VII.

Rodrigues Capitulo, A. \& J. Muzón, 1989. Nuevas citas y localidades para los Odonata de la Argentina. Revista de la Sociedad Entomológica Argentina 47 [1988]: 143-156.

Westfall, M.J., 1992. Notes on Micrathyria, with descriptions of M. pseudeximia sp. n., $M$. occipita sp. n., M. dunklei sp. n. and $M$. divergens sp. n. (Anisoptera: Libellulidae). Odonatologica 21: 203-218. 